\title{
BIODIVERSITAS IKAN KARANG DI WILAYAH BENTANG LAUT LESSER SUNDA BANDA (KAB. FLORES TIMUR, ALOR DAN MALUKU BARAT DAYA (MBD)), INDONESIA
}

\section{REEF FISHES BIODIVERSITY OF LESSER SUNDA-BANDA SEASCAPE (EAST FLORES, ALOR AND SOUTH WEST MALUKU DISTRICT) IN INDONESIA}

Fakhrizal Setiawan ${ }^{1 *}$, Azhar Muttaqin 1 , Estradivari ${ }^{2}$, Efin Muttaqin 1 , Sukmaraharja A. Tarigan ${ }^{1}$, Tutus Wijanarko ${ }^{2}$, Khaifin ${ }^{2}$, Nara Wisesa ${ }^{2}$, Aditano Y. Retrawimbi ${ }^{2}$, Muhidin ${ }^{3}$, Hedra Akhrari ${ }^{4}$ dan Sanca Sadewa ${ }^{4}$

${ }^{1}$ Wildlife Conservation Society - Indonesia Marine Program, Jl. Tampomas No. 35, Bogor, Jawa Barat, 16151

${ }^{2}$ World Wildlife Fund - Indonesia, Graha Simatupang Tower 2 Unit C, $7^{\text {th }}-11^{\text {th }}$ Floor, JI. TB. Simatupang, Jakarta, 12540

${ }^{3}$ Fisheries Diving Club - FPIK-IPB, Lt. Dasar Gedung FPIK, JIn. Rasamala No. 1 Kampus IPB Darmaga Bogor, 16680

${ }^{4}$ Postgraduated student-FPIK-IPB, JIn. Rasamala No. 1 Kampus IPB Darmaga Bogor, 16680

"Corresponding author email: fsetiawan@wcs.org

Submitted: 13 April 2016 / Revised: 23 Februari 2017 / Accepted: 25 April 2017

http://dx.doi.org/10.21107/jk.v10i1.1349

\begin{abstract}
A total of 62 dive sites were made to provide an overview of reef fish found in the border region of the Province of NTT and Maluku in Indonesia. Live coral cover shows the general condition of the coral cover is in good category with an average value of $62.51 \%$. Reef fish found in this survey consists of 468 species in 47 Famili reef fish reef where fish biomass is highest Kab. MBD (average

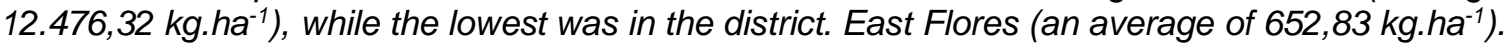
The value of reef fish abundance is highest in the district MBD (average 13.308 ind.ha $^{-1}$ ) and the lowest was in the district East Flores (average 1.502,23 ind.ha ${ }^{-1}$ ). Reef fish community structure based-weinner Shannon index $\left(H^{\prime}\right)$ was the medium category, evenness indice value $(E)$ in the category volatile and the value of dominance $(C)$ enters a low dominance so that the ecosystem is still in good condition. The similarity of species of reef fish using cluster analysis results at the level of scaling 66.37\% and MDS (Multi Dimensional Scaling) breaks down into two groups of reef fish that reef fish in the district Alor and East Florest and district of Southwest Maluku in other group. Results of the cluster analysis and MDS showed Alor and East Flores regency in NTT Prvince incoming Lesser Sunda seascapes have different reef fish by the District of Southwest Maluku in Maluku Province incoming Sunda Banda seascapes. Overall reef fish in the district. MBD has a very high potential views of abundance, biomass and other ecological values. This location can be developed into a potential source of animal protein for the people there as well as national level.
\end{abstract}

Keywords: Reef fishes, biomass, abundance, Lesser Sunda, sunda banda seascape

\section{ABSTRAK}

Penelitian yang tersebar di 62 titik penyelaman dilakukan untuk memberi gambaran mengenai ikan karang yang terdapat di wilayah perbatasan Propinsi NTT dan Maluku di Indonesia. Tutupan karang hidup menunjukan umumnya kondisi tutupan karang berada pada kategori baik dengan nilai ratarata $62,51 \%$. Ikan karang yang ditemukan dalam survei ini terdiri dari 468 spesies dalam 47 famili ikan karang dimana biomassa ikan karang tertinggi terdapat Kab. MBD (Rata-rata 12.476,32 kg.ha1) sedangkan yang terendah terdapat di Kab. Flores Timur (rata-rata 652,83 kg.ha-1). Nilai Kelimpahan ikan karang tertinggi terdapat di Kab. MBD (rata-rata 13.308 ind.ha $^{-1}$ ) dan yang terendah terdapat di Kab. Flores Timur (rata-rata 1.502.23 ind.ha-1). Struktur komunitas ikan karang berdasarkan indeks shanon-weinner ( $\left.H^{\prime}\right)$ berada kategori sedang, nilai indeks keseragaman $(E)$ 
masuk kategori labil dan nilai dominansi (C) masuk dominansi rendah sehingga ekosistem masih dalam kondisi baik.Kesamaan spesies ikan karang menggunakan hasil cluster analysis pada taraf penskalaan 66,37\% dan MDS (Multi Dimensional Scalling) mengelompokkan ikan karang kedalam 2 grup yaitu ikan karang di wilayah Kab. Alor dan Flores Timur dan Kabupaten Maluku Barat Daya di kolompok lainnya. Hasil dari analisis klatser dan MDS memperlihatkan Kab. Alor dan Flores timur di Provinsi NTT yang masuk wilayah geografis Lesser Sunda memiliki perbedaan ikan karang dengan Kab. Maluku Barat Daya di Provinsi Maluku yang secara geografis masuk area Bandaseascapes. Secara keseluruhan ikan karang di Kab. MBD memiliki potensi yang sangat tinggi dilihat dari kelimpahan, biomasa dan nilai ekologi lainnya. Lokasi ini bisa dikembangkan menjadi sumber protein hewani yang potensial bagi masyarakat disana maupun tingkat nasional.

Kata kunci: Ikan karang, biomassa, kelimpahan, bentang laut, Lesser Sunda, Sunda banda

\section{PENDAHULUAN}

Indonesia merupakan salah satu negara kepulauan yang termasuk kedalam segitiga terumbu karang dunia serta memiliki kekayaan sumber daya laut khususnya terumbu karang yang sangat potensial. Luas terumbu karang Indonesia sebesar 42.000 $\mathrm{km}^{2}$ atau $16,5 \%$ dari luasan terumbu karang dunia (Salim, 2012). Hasil kajian coremap, 2014 di 1184 titik pengamatan di seluruh Indonesia menunjukkan hanya 5,32\% tutupan karang yang dalam kondisi sangat baik, $27,20 \%$ dalam kondisi baik, 37,42 cukup dan $30,07 \%$ yang kurang. Namun wilayah di Kab. Alor Flores timur dan MBD masih sedikit tergali informasinya. Wilayah Nusa Tenggara dan Maluku berdasarkan urutan prioritas geografi di Indonesia menempati urutan ketiga dan kedua setelah Papua (Huffard et al., 2012), dikarenakan keragaman dan endemisitas biota penghuninya baik biota terestrial maupun lautnya. Monk et al., (1997) menyebut wilayah 3 kabupaten ini termasuk sebagai Lesser Sunda meski masih banyak perdebatan mengenai penamaan ini.

Wilayah di bagian Kab. Alor yaitu di Selat Pantar sudah di tetapkan sebagai kawasan Konservasi Perairan Daerah (KKPD) dan Kab. Flores Timur (wilayah Adonara, Solor dan sebagian Flores Timur) diusulkan sebagai calon KKPD sedangkan Kab. Maluku Barat Daya hingga saat ini masih belum ada kawasan konservasi yang dibentuk. Wilayah ini berdasarkan Ilahude dan Gordon (1996) dilewati arus lintas Indonesia (ARLINDO) yang berasal dari Samudera Pasifik memasuki perairan indonesia melewati Selat Makasar, Laut Banda, Laut Maluku, dan Laut Flores menuju Samudera Hindia dan lokasi penelitian ini masuk di wilayah tersebut. Hasanuddin (1998) menduga bahwa sepanjang tahun, ARLINDO menciptakan terjadinya rangkaian proses lain yang mengiringi perjalanannya seperti, turbulensi, upwelling, downwelling, dan sebagainya. Hal ini menjelaskan mengapa beberapa lokasi penyelaman di wilayah ini memiliki suhu air yang dingin berkisar $26^{\circ}$ celcius. Menurut Tomascik et al., (1997), ARLINDO bisa dijadikan indikator kesuburan perairan.

Indikasi paling mudah dilihat untuk kesuburan perairan yaitu melimpahnya ikan di daerah tersebut termasuk ikan karang. Menurut Adrim (2007) dan Hallacher (2003) ikan karang merupakan taksa terbesar dari kelompok vertebrata yang berasosiasi dengan terumbu karang. Keanekaragaman spesies ikan karang mempunyai hubungan yang erat dengan keberadaan terumbu karang di daerah tersebut. Tingkah laku ikan karang baik kecenderungan untuk berkelompok, mencari makan dan bertahan dari serangan predator tidak terlepas dari lingkungan yang berstruktur akibat bentuk terumbu yang komplek (Hutomo, 1995). Perbedaan dalam habitat dipengaruhi oleh aktivitas gelombang, arus, cahaya, ketersediaan alga, plankton dan makanan lain serta kelimpahan bentuk dan variasi koral termasuk struktur terlindung lainnya memberikan kombinasi variasi yang besar dalam kelompok ikan niche mereka (Hieske and Myers, 2001).

Odum (1971) menyatakan bahwa komunitas merupakan suatu kumpulan dengan kesatuan komposisi taksonomik serta secara relatif tampak seragam dengan organisasi trofik serta pola metabolis tertentu. Ikan-ikan karang sebagai suatu komunitas memiliki habitat yang berbeda tetapi banyak spesies yang terdapat pada lebih dari satu habitat. Umumnya tiap spesies ikan karang yang 
mendiami suatu perairan memiliki kesukaan habitat tertentu karena terumbu karang menyediakan variasi habitat yang luas, setiap habitat didiami oleh spesies yang karakteristik/khas (Hutomo, 1986; Hieske and Myers, 2001).

Menurut English et al. (1994), bahwa ruang merupakan sumber daya terpenting sebagai faktor pembatas utama bagi kelimpahan ikan karang di ekosistem terumbu karang dibandingkan makanan. Suatu komunitas dikatakan mempunyai keanekaragaman spesies tinggi jika kelimpahan spesies yang ada atau proporsi antar spesies secara keseluruhan sama banyak atau hampir sama banyak. Pada komunitas yang mempunyai keanekaragaman tinggi, jarang ditemukan spesies yang dominan, atau dengan kata lain nilai dominasi komunitas berbanding terbalik dengan keanekaragaman ekologi (Odum, 1971). Informasi mengenai kondisi ekosistem terumbu karang di 3 kabupaten ini masih sedikit sekali yang tergali dikarenakan lokasinya yang sulit dijangkau dan keterbatasan sarana prasarana yang ada. Bahkan wilayah di Kab. Maluku Barat Daya ini lebih dikenal dengan sebutan forgotten islands karena letaknya yang jauh dan sulit diakses (Campbell and Crueck, 2014). Biota ikan karang khususnya ikan konsumsi merupakan sumber protein penting bagi penduduk di wilayah ini, namun belum banyak diteliti. Tujuan dari studi ini yaitu untuk mengetahui jenis, kelimpahan, sebaran spasial, ekologi ikan karangnya serta stok alami ikan karang tersebut. Selain itu diharapkan pula hasil penelitian ini dapat bermanfaat sebagai data dasar dalam pengambilan kebijakan yang berkaitan dengan pesisir bagi semua pihak dimanapun.

\section{MATERI DAN METODE}

\section{Lokasi dan waktu kegiatan}

Lokasi kegiatan survei terumbu karang dan ikan karang ini meliputi 62 lokasi penyelaman yang terbesar di 3 kabupaten yang meliputi Kab. Flores Timur (18 titik), Alor (24 titik) dan Maluku Barat Daya (20 titik). Survey dilakukan dalam dua tahap yaitu tahap pertama (13 Maret s/d 1 April 2014) untuk wilayah Kab. Flores Timur dan Alor dan tahap kedua (1 s/d 10 Oktober 2014) untuk Kab. Maluku Barat Daya.

Tabel 1. Lokasi dan titik geografis lokasi penelitian

\begin{tabular}{llrr}
\hline Kabupaten & Lokasi & Lintang & \multicolumn{1}{c}{ Bujur } \\
\hline & Mahi & 8.406566667 & 124.3389278 \\
& Pulau Batang & 8.220638889 & 124.0820278 \\
Pulau Kambing & 8.437583333 & 123.8757222 \\
Karang Le & 8.328436111 & 125.1332167 \\
Kolana Utara & 8.253308333 & 125.1421444 \\
Mademang & 8.391016667 & 124.8199389 \\
Marutaing 2 & 8.309444444 & 125.1340028 \\
Mausamang & 8.168841667 & 125.1072 \\
Alor & Sawarana & 8.355372222 & 125.0370167 \\
& Tanjung soyang & 8.222480556 & 125.1367222 \\
& Taramana & 8.165983333 & 124.8538889 \\
& Baulaung & 8.279333333 & 124.1797222 \\
& Desa Pandai & 8.195366667 & 124.2426 \\
& Lemma & 8.328666667 & 123.0022778 \\
& Pulau Kangge & 8.371416667 & 123.8988333 \\
& Pulau Rusa & 8.412333333 & 123.2959444 \\
& Bangkalan/Desa Ombay & 8.269777778 & 124.2999444 \\
Clownfish Valley & -8.31018 & 124.3696111 \\
& Desa Aimole & 8.179263889 & 124.4273444
\end{tabular}




\begin{tabular}{|c|c|c|c|}
\hline & Pulau Pura & 8.324427778 & 124.3377139 \\
\hline & Pulau Ternate & 8.2152 & 124.37914 \\
\hline & The Babylon & -8.222388889 & 124.36208 \\
\hline & The Boardroom & -8.28231 & 124.3264 \\
\hline \multirow{19}{*}{ Flores Timur } & Hurung $B$ & 8.28675 & 123.0610833 \\
\hline & Karang Sarbete & -8.13502 & 123.01582 \\
\hline & Lowoingu B & 8.433388889 & 122.8164444 \\
\hline & Watowati B & 8.272416667 & 123.0154444 \\
\hline & Watupeni & -8.239083333 & 123.3350833 \\
\hline & Waybalun B & 8.350388889 & 122.9712222 \\
\hline & Adonara B & 8.240333333 & 123.1321667 \\
\hline & Aran B & 8.235444444 & 123.1659444 \\
\hline & Batu Payung B & 8.232666667 & 122.7448611 \\
\hline & Desa Balaweling B & 8.227083333 & 122.967 \\
\hline & Ile Padung B & 8.297 & 122.8146667 \\
\hline & Kolidateng B & 8.141027778 & 122.9785556 \\
\hline & Koten B & 8.083361111 & 122.8361111 \\
\hline & Lama Ojan & 8.195777778 & 122.8199167 \\
\hline & Lamawalang B & 8.545694444 & 122.9636944 \\
\hline & Lato B & 8.343 & 122.7736389 \\
\hline & Pulau Tiga B & 8.594138889 & 122.8793333 \\
\hline & Pulo Mas B & 8.154333333 & 123.037 \\
\hline & Tanjung Naga B & 8.458333333 & 123.1497778 \\
\hline \multirow{20}{*}{ Maluku Barat Daya } & Amortaun & -8.190333333 & 128.3813889 \\
\hline & Babar Sea mount & -8.02936 & 129.6622 \\
\hline & Buffalo Reef & -8.15647 & 128.55646 \\
\hline & Grouper Fate & -8.291305556 & 128.4136111 \\
\hline & Jagotutun (Magic Corner) & -8.349666667 & 128.5208611 \\
\hline & North Moa & -8.102805556 & 127.7855833 \\
\hline & North Reong & -7.66451 & 125.91559 \\
\hline & North Romang & -7.49159 & 127.38171 \\
\hline & North West Lakor & -8.205361111 & 128.0967778 \\
\hline & Pualu Nyata & -7.511333333 & 127.2812222 \\
\hline & Pulau Kelapa & -8.18241 & 128.80092 \\
\hline & Pulau Laut & -7.522416667 & 127.5507778 \\
\hline & South Reong & -7.679555556 & 125.91625 \\
\hline & Tanjung Nunukae & -7.777666667 & 125.8576111 \\
\hline & Tanjung Ruswawan & -8.200361111 & 128.1899444 \\
\hline & Tanjung Siota & -8.129222222 & 127.9290833 \\
\hline & Tanjung Wahar & -8.19528 & 128.82611 \\
\hline & Tanjung Yautu & -8.110111111 & 127.7621944 \\
\hline & To Dai For & -7.56973 & 129.71802 \\
\hline & West Moa & -8.139027778 & 127.7841389 \\
\hline
\end{tabular}




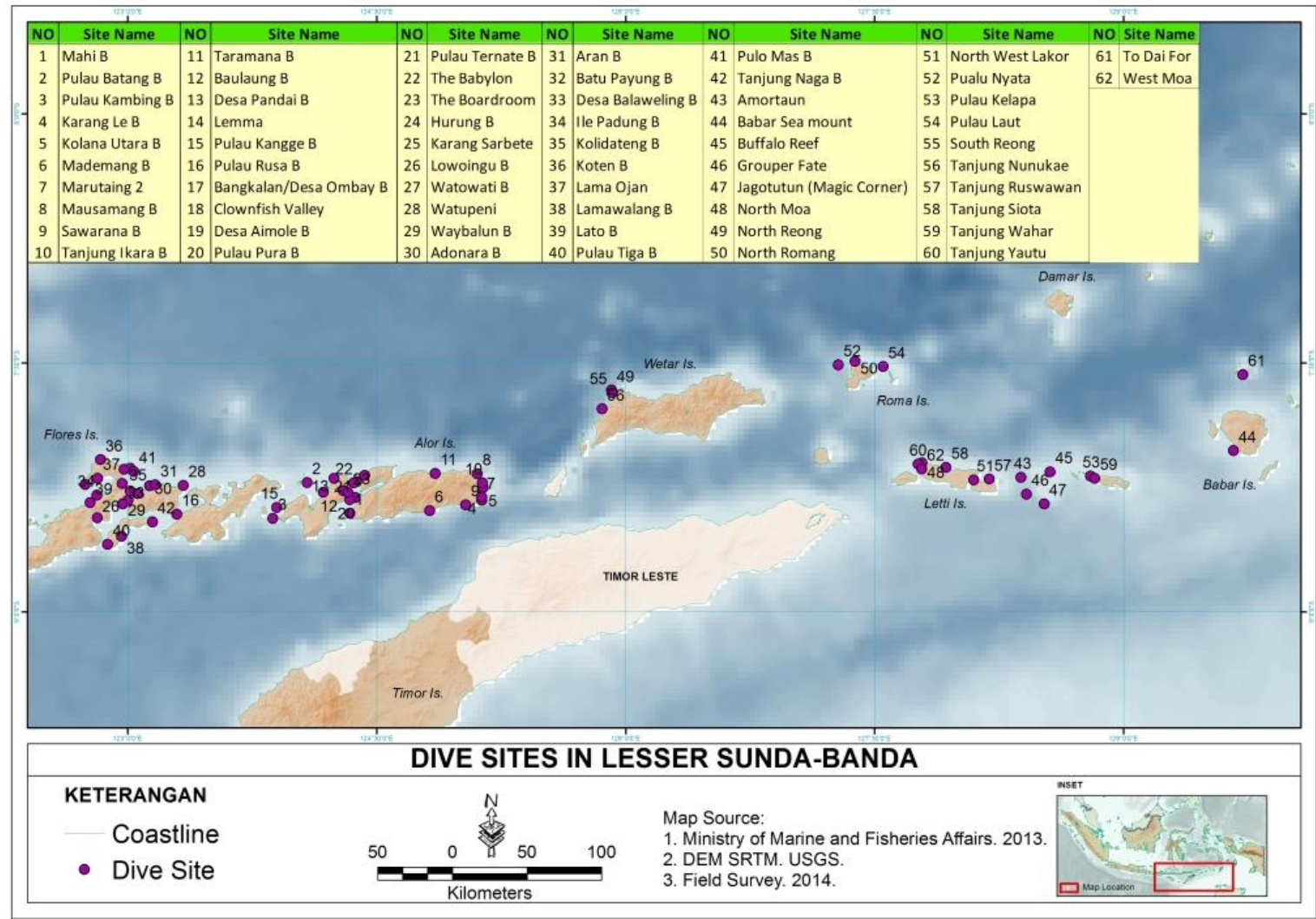

Gambar 1. Peta lokasi survei ekologi di Kab. Flores Timur, Alor dan Maluku Barat Daya.

Survey dilakukan menggunakan live aboard (semua kegiatan penelitian dan tempat tinggal dilakukan dari kapal) dikarenakan sulitnya akses untuk melakukan aktifitas penyelaman dari darat. Penentuan survei point umumnya disesuaikan dengan kondisi keterwakilan lokasi. Jumlah titik survei untuk pengamatan terumbu karang dan ikan ditetapkan di lokasi yang mewakili kondisi perairan ekosistem terumbu karang di 3 kabupaten tersebut.

\section{Metode survei terumbu karang dan ikan karang}

Pengambilan data tutupan karang keras dan macrobenthos dilakukan dengan metode transek titik-menyinggung atau Point Intercept Transect (PIT) dengan mencatat 100 titik substrat pada transek sepanjang 50 $m$ dengan ulangan sebanyak 5 kali pada satu kedalaman yaitu (10-12 meter) (Marnane et al., 2003; Hill and Wilkinson, 2004; Manuputy dan Djuwariah, 2009; Yulianto et al., 2012). Survey ikan karang menggunakan metode visual sensus pada transek yang sama dengan karang, transek pengamatan menggunakan garis maya yang ditarik paralel dengan transek garis membentuk luasan persegi panjang. Transek jenis ini dikenal dengan transek sabuk (Dartnall dan Jones (1986); English et al., (1994); Hill and Wilkinson, 2004, Yulianto et al., 2012). Identifikasi ikan berdasarkan Allen (2003); Kuiter and Tonozuka (2001a,b,c); Kuiter (2001), sedangkan konstanta laju pertumbuhan $a$ dan $b$ untuk perhitungan biomassa ikan karang didapat dari Froese and Pauly (2010) dan Kulbicki (2005).

\section{Pengolahan dan analisis data}

Analisis data tutupan karang (English et al. 1997; Manuputy dan Juwariah, 2009):

$$
\begin{aligned}
& \begin{array}{l}
\% \text { Penutupan substrat }= \\
\sum \text { titik komponen ke-i pada transek } \\
100 \text { titik } \times \text { n }
\end{array} \text { X } 100 \%,
\end{aligned}
$$

Analisis ikan karang, meliputi:

Biomassa ikan karang: $\mathbf{W}=\mathbf{a} \times \mathbf{x} \mathbf{L}^{\mathbf{b}}$, dimana: W: Berat (gr); L : Panjang Total (cm); a \& b : indeks spesifik (per species) (Effendie, 1979; Kulbicki, 2005; Marnane et al., 2003).

Kelimpahan komunitas ikan karang:

$\mathbf{X i}=\mathbf{n i} / \mathbf{A}$ 
dengan: $\mathrm{Xi}=$ Kelimpahan komunitas terpilih ke-i (individu/koloni per meter persegi); $\mathrm{ni}=$ Jumlah total komunitas terpilih pada stasiun pengamatan ke-i; $\mathrm{A}=$ Luas transek pengamatan (Odum, 1993).

Indeks ekologi (Ludwig and Reynolds, 1988) ikan karang meliputi:

Indeks keanekaragaman Shanon-Weiner: H'

$$
=-\sum_{i=1}^{S} \mathbf{p i} / \boldsymbol{n} \mathbf{p i} \text {, }
$$

Indeks kesamaan: $\mathbf{E}=\mathbf{H}$ '/ H maks,

dan indeks dominansi:

$\mathbf{D}=\sum_{i=1}^{S} \mathbf{p i}^{2}$,

Tingkat pengelompokkan berdasarkan kesamaan species ikan karang digunakan Indeks kesamaan Bray-Curtis (Krebs, 1989): $\mathbf{B}=\frac{\sum(X i j-X i k)}{\sum(X i j-X i k)}$,

dimana: $\mathrm{B}=$ Pengukuran Ketidaksamaan Bray-Curtis, $X_{i j}, X_{i k}=$ No. Individu dalam species I dalam tiap sampel, I,j = baris dan kolom ke-1,2,3....x. Pengukuran indeks kesamaan Bray-Curtis dapat menggunakan rumus komplemen indeks pengukuran BrayCurtis yaitu 1,0 - B (Krebs, 1989). Hasil perhitungan indeks Bray Curtis ditampilkan dalam bentuk bentuk dendogram. Pengolahan data baik Cluster Analysis (CA) menggunakan perangkat lunak Minitab sedangkan Multi Dimensional Scalling (MDS) menggunakan perangkat lunak SPSS 12.

\section{HASIL DAN PEMBAHASAN}

Kondisi substrat dasar dikelompokkan kedalam kategori karang keras, karang lunak, alga, spons, abiotik dan others. Kategori alga terdiri dari segala jenis alga baik makro dan mikro termasuk substrat yang telah diselimuti alga termasuk karang mati sedangkan others terdiri dari semua jenis invertebrata bentik yang tidak tergolong karang. Substrat yang tergolong abiotik terdiri dari pasir, patahan karang (rubble) dan batu. Substrat merupakan salah satu hal terpenting bagi pertumbuhan karang. Suatu area yang memiliki substrat stabil akan lebih memiliki peluang yang besar untuk ditumbuhi oleh planula karang dibandingkan dengan area yang memiliki substrat tidak stabil. Menurut Richmond (1997), menjelaskan bahwa planula karang lebih memilih untuk menempel di substrat yang keras dibandingkan di substrat yang tidak stabil.
Tutupan substrat dasar dari 62 lokasi penyelaman dari 3 kabupaten memperlihatkan tutupan alga dengan tutupan tertinggi terdapat di lokasi Boardroom Kab. Alor $(32,33 \%)$ disusul di lokasi Lato Kab. Flores Timur (23\%) dan di Kab. Maluku Barat Daya yaitu To Dai For (22\%), nilai ini masih lebih rendah dibandingan dengan lokasi yang memiliki hamparan terumbu karang cukup luas namun tutupan alganya tinggi sebesar $56 \%$, yaitu di Sulawesi Selatan Pulau Barrang Caddi (Arifin dan Kepel, 2013). Meningkatnya tutupan alga dalam hal ini terdiri dari makroalga dan mikroalga (contoh: Caulerpa, Padina, Sargassum, Halimeda, Turf Alga, Coraline alga, dll) mengindikasikan adanya kompetisi ruang dengan terumbu karang. Menurut McCook (2001) tutupan alga yang luas, akan menimbulkan potensi adanya kompetisi ruang dengan terumbu karang. Death Coral with Algae (DCA) disini dipisahkan untuk melihat karang yang terselimuti dengan alga memiliki tutupan yang tinggi atau tidak. Tutupan DCA tertinggi terdapat di lokasi Aransebesar 23,33\% (Gambar 2), nilai ini masih lebih rendah dibandingkan dengan di Pulau Lombok yang tutupan DCA rata-ratanya sebesar $42,62 \%$ (Pardede et al., 2014). Bertumbuhnya beberapa jenis alga yang hidup di lokasi tersebut akan mempengaruhi pertumbuhan rekrutmen karangnya (Richmond, 1997).

Karang keras dengan tutupan tertinggi di Desa Balaweling Kab. Flotim (71,33 \%) dan terendah di Clownfish Valley di Kab. Alor $(6,33 \%)$ dengan rata-rata $35,70 \%$, nilai ini masih lebih rendah dibandingkan dengan di Kab. Maluku Tenggara Barat (Kep. Tanimbar) dengan rata-rata tutupan karang keras sebesar 52\% (Setiawan et al., 2015) namun lebih baik dibandingkan di Pulau Lombok sebesar 29,52\% (Pardede et al., 2014). Rendahnya tutupan karang keras yang terdapat di beberapa lokasi penyelaman pada 3 kabupaten, dimungkinkan karena adanya penangkapan ikan yang tidak ramah lingkungan ataupun penangkapan yang berlebihan.Menurut Burke et al. (2011) menjelaskan faktor ancaman lokal yang datang dari manusia pada terumbu karang salah satunya adalah penangkapan ikan yang berlebihan dan penangkapan yang merusak. 


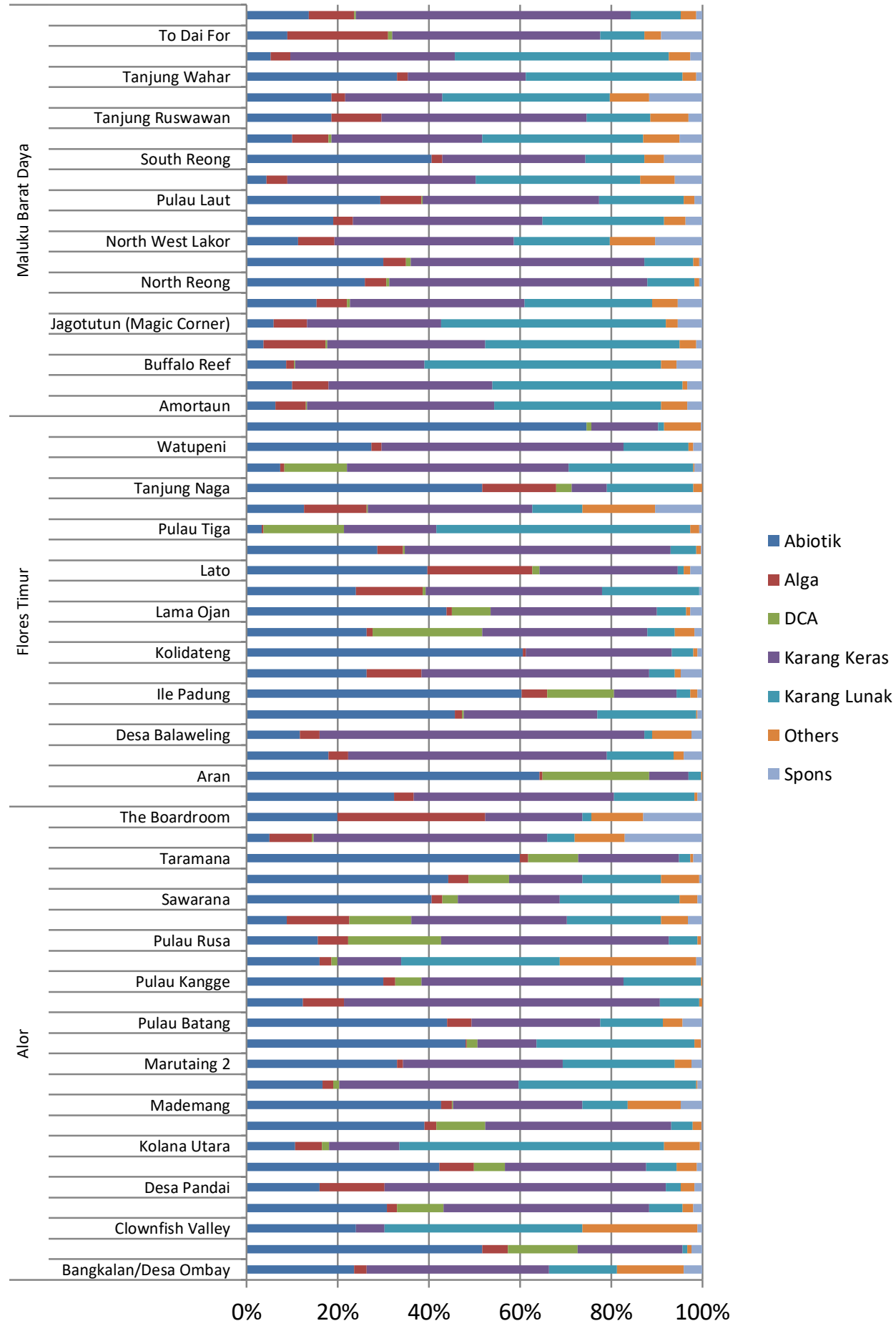

Gambar 2.Histogram tutupan substrat dasar di 3 kabupaten.

Komponen others non karang seperti (Linckia sp., Holoturidae, Crinoid, Diadema sp., dll) tertinggi terdapat di Pulau Pura, Kab. Alor $(30,00 \%)$ dan satu lokasi di Kab. Flotim, Lamawalang tidak ditemukan komponen others di transeknya. Karang lunak dengan tutupan tertinggi sebesar $58,17 \%$ terdapat di Kolana Utara Kab. Alor, sedangkan tutupan karang lunak terendah terdapat di Baulaung (1\%) (Gambar 2). Karang lunak sendiri merupakan salah satu hewan penyusun ekosistem terumbu karang dan sebagai pemasok terbesar senyawa karbonat bagi pembentuk terumbu (Manuputty, 1990). Sehingga pertumbuhan karang lunak cukup 
memberikan pengaruh terhadap pertumbuhan terumbu karang.

Tutupan karang hidup berdasarkan kepmen LH no 4 Tahun 2001 dan kriteria standar kesehatan karang berdasarkan Zamani dan Madduppa (2011), memperlihatkan kategori yang tersebar dari buruk hingga baik sekali di 3 kabupaten yaitu Kab. Flores Timur, Alor dan Maluku Barat Daya (Tabel 2). Tutupan karang hidup didapat dari penjumlahan antara tutupan karang keras dan karang lunak di tiap-tiap lokasi. Lokasi dengan tutupan karang hidup tertinggi terdapat di lokasi Tanjung Yautu di Kab. Maluku Barat Daya sebesar 83\% dan terendah terdapat di lokasi Arane di Kab. Flores Timur sebesar $11,33 \%$ dengan nilai rata-rata $55,36 \%$ yang masuk kategori baik. Nilai ini masih tidak jauh berbeda dengan hasil penelitian di Pesisir
Barat Pulau Kei Kecil, Kab. Maluku Tengara (Afandi dan Supeni, 2014) dengan rata rata tutupan karang hidupnya sebesar 53,11\%. Selain karang keras, karang lunak memiliki peranan penting terhadap kondisi terumbu karang. Kondisi tutupan karang keras yang rendah sangat terbantu dengan tingginya nilai tutupan karang lunak. Pada kondisi yang rusak, karang lunak merupakan penyusun utama dari ekosistem terumbu karang dimasa pemulihan (Manuputty, 1996). Indonesia termasuk kedalam bagian IndoPasifik Barat, memiliki penyebaran karang lunak (Alcyoniidae) yang luas dan dalam jumlah yang besar (Bayer, 1956 dalam Manuputty, 1996), sehingga kondisi terumbu karang yang terdapat di 3 kabupaten ini, sangat terbantu dengan adanya karang lunak tersebut.

Tabel 2. Persentase tutupan karang hidup di 3 kabupaten.

\begin{tabular}{|c|c|c|c|c|c|}
\hline Region & Lokasi Penyelaman & \multicolumn{2}{|c|}{ Koordinat } & $\begin{array}{c}\% \\
\text { Karang } \\
\text { Hidup }\end{array}$ & Kategori \\
\hline \multirow{23}{*}{ Alor } & $\begin{array}{l}\text { Bangkalan/Desa } \\
\text { Ombay }\end{array}$ & -8.26978 & 124.2999 & 55.00 & Baik \\
\hline & Baulaung & -8.27933 & 124.1797 & 24.00 & Buruk \\
\hline & Clownfish Valley & -8.31018 & 124.3696 & 49.67 & Sedang \\
\hline & Desa Aimole & -8.17926 & 124.4273 & 52.50 & Baik \\
\hline & Desa Pandai & -8.19537 & 124.2426 & 65.00 & Baik \\
\hline & Karang Le & -8.32844 & 125.1332 & 37.67 & Sedang \\
\hline & Kolana Utara & -8.25331 & 125.1421 & 73.50 & Baik \\
\hline & Lemma & -8.32867 & 123.0023 & 45.50 & Sedang \\
\hline & Mademang & -8.39102 & 124.8199 & 38.33 & Sedang \\
\hline & Mahi & -8.40657 & 124.3389 & 78.33 & Baik Sekali \\
\hline & Marutaing 2 & -8.30944 & 125.134 & 59.67 & Baik \\
\hline & Mausamang & -8.16884 & 125.1072 & 47.67 & Sedang \\
\hline & Pulau Batang & -8.22064 & 124.082 & 42.00 & Sedang \\
\hline & Pulau Kambing & -8.43758 & 123.8757 & 78.00 & Baik Sekali \\
\hline & Pulau Kangge & -8.37142 & 123.8988 & 61.33 & Baik \\
\hline & Pulau Pura & -8.32443 & 124.3377 & 48.67 & Sedang \\
\hline & Pulau Rusa & -8.41233 & 123.2959 & 56.33 & Baik \\
\hline & Pulau Ternate & -8.2152 & 124.3791 & 54.83 & Baik \\
\hline & Sawarana & -8.35537 & 125.037 & 48.67 & Sedang \\
\hline & Tanjung soyang & -8.22248 & 125.1367 & 33.33 & Sedang \\
\hline & Taramana & -8.16598 & 124.8539 & 24.50 & Buruk \\
\hline & The Babylon & -8.22239 & 124.3621 & 57.33 & Baik \\
\hline & The Boardroom & -8.28231 & 124.3264 & 23.33 & Buruk \\
\hline Flores Timur & Adonara & -8.24033 & 123.1322 & 61.67 & Baik \\
\hline
\end{tabular}




\begin{tabular}{|c|c|c|c|c|c|}
\hline & Aran & -8.23544 & 123.1659 & 11.33 & Buruk \\
\hline & Batu Payung & -8.23267 & 122.7449 & 71.33 & Baik \\
\hline & Desa Balaweling & -8.22708 & 122.967 & 73.00 & Baik \\
\hline & Hurung & -8.28675 & 123.0611 & 51.00 & Baik \\
\hline & Ile Padung & -8.297 & 122.8147 & 16.67 & Buruk \\
\hline & Karang Sarbete & -8.13502 & 123.0158 & 55.67 & Baik \\
\hline & Kolidateng & -8.14103 & 122.9786 & 36.67 & Sedang \\
\hline & Koten & -8.08336 & 122.8361 & 42.33 & Sedang \\
\hline & Lama Ojan & -8.19578 & 122.8199 & 43.00 & Sedang \\
\hline & Lamawalang & -8.54569 & 122.9637 & 60.00 & Baik \\
\hline & Lato & -8.343 & 122.7736 & 31.67 & Sedang \\
\hline & Lowoingu & -8.43339 & 122.8164 & 64.00 & Baik \\
\hline & Pulau Tiga & -8.59414 & 122.8793 & 76.00 & Baik Sekali \\
\hline & Pulo Mas & -8.15433 & 123.037 & 47.00 & Sedang \\
\hline & Tanjung Naga & -8.45833 & 123.1498 & 26.67 & Sedang \\
\hline & Watowati & -8.27242 & 123.0154 & 76.00 & Baik Sekali \\
\hline & Watupeni & -8.23908 & 123.3351 & 67.33 & Baik \\
\hline & Waybalun & -8.35039 & 122.9712 & 16.00 & Buruk \\
\hline \multirow{20}{*}{$\begin{array}{c}\text { Maluku Barat } \\
\text { Daya }\end{array}$} & Amortaun & -8.19033 & 128.3814 & 77.67 & Baik Sekali \\
\hline & Babar Sea mount & -8.02936 & 129.6622 & 77.67 & Baik Sekali \\
\hline & Buffalo Reef & -8.15647 & 128.5565 & 80.33 & Baik Sekali \\
\hline & \multirow{2}{*}{$\begin{array}{l}\text { Grouper Fate } \\
\text { Jagotutun (Magic } \\
\text { Corner) }\end{array}$} & -8.29131 & 128.4136 & 77.33 & Baik Sekali \\
\hline & & -8.34967 & 128.5209 & 78.67 & Baik Sekali \\
\hline & North Moa & -8.10281 & 127.7856 & 66.33 & Baik \\
\hline & North Reong & -7.66451 & 125.9156 & 67.00 & Baik \\
\hline & North Romang & -7.49159 & 127.3817 & 62.00 & Baik \\
\hline & North West Lakor & -8.20536 & 128.0968 & 60.33 & Baik \\
\hline & Pulau Kelapa & -8.18241 & 128.8009 & 68.33 & Baik \\
\hline & Pulau Laut & -7.52242 & 127.5508 & 57.33 & Baik \\
\hline & Pulau Nyata & -7.51133 & 127.2812 & 77.33 & Baik Sekali \\
\hline & South Reong & -7.67956 & 125.9163 & 44.33 & Sedang \\
\hline & Tanjung Nunukae & -7.77767 & 125.8576 & 68.33 & Baik \\
\hline & Tanjung Ruswawan & -8.20036 & 128.1899 & 59.00 & Baik \\
\hline & Tanjung Siota & -8.12922 & 127.9291 & 58.00 & Baik \\
\hline & Tanjung Wahar & -8.19528 & 128.8261 & 60.33 & Baik \\
\hline & Tanjung Yautu & -8.11011 & 127.7622 & 83.00 & Baik Sekali \\
\hline & To Dai For & -7.56973 & 129.718 & 55.33 & Baik \\
\hline & West Moa & -8.13903 & 127.7841 & 71.33 & Baik \\
\hline
\end{tabular}

\section{Ikan Karang}

Survey kali ini didapatkan 468 spesies ikan karang dari 47 Famili yang tersebar di 3 kabupaten. Sebanyak $82 \%$ dari seluruh spesies ikan karang yang ditemukan berasal dari 16 famili terbanyak yaitu Labridae, Pomacentridae, Serranidae, Acanthuridae, Chaetodontidae, Scaridae, Lutjanidae, Holocentridae, Pomacentridae, 
Nemipteridae, Siganidae, Mullidae, Lethrinidae, Siganidae, Mullidae, Lethrinidae, Haemullidae, Caesionidae dan Balistidae (Gambar 3). Famili Labridae merupakan kelompok terbesar ikan karang dimana memiliki anggota lebih dari 500 species dari 90 genera (Kuiter, 2010) sedang family lainnya memiliki species yang kurang dari Labridae bahkan ada family seperti Zanclidae yang hanya memiliki satu species. Jika berdasarkan kelimpahannya $78 \%$ dari seluruh famili yang ada didominasi oleh famili
Caesionidae $(40 \%)$, Pomacentridae $(21 \%)$, Serranidae (6\%), Acanthuridae (6\%), Labridae $(5 \%)$ dan sisanya $23 \%$ terdiri dari Balistidae, Carangidae, Holocentridae, Chaetodontidae, Scombridae, dan others (Gambar 3). Famili-family yang memiliki kelimpahan tinggi umumnya dijumpai dalam keadaan bergerombol (schooling) atau jumlahnya banyak meski tidak bergerombol, hal inilah yang menyebabkan jumlahnya melimpah dibandingkan family lain.

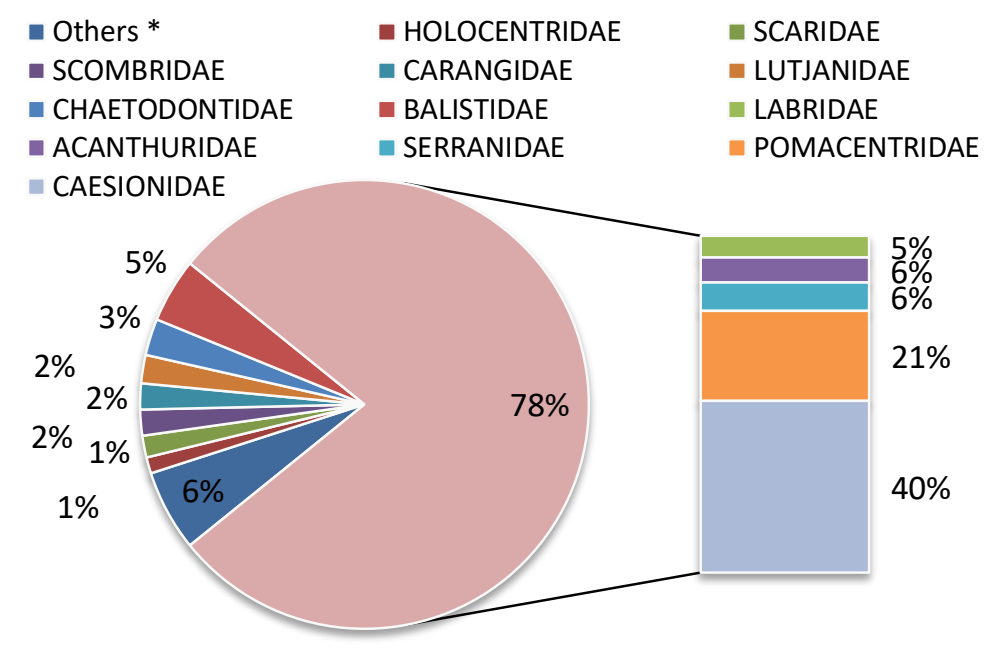

Gambar 3. Komposisi famili yang memiliki kelimpahan terbesar (kanan). Others*: Famili yang kelimpahannya $<1000$ individu (kanan).

\section{Biomassa dan Kelimpahan Ikan Karang}

Biomassa ikan karang tertinggi terdapat di Lokasi Babar Sea Mount $(42.284,78 \mathrm{Kg} / \mathrm{Ha})$ di Kab. MBD sedangkan yang terendah terdapat di lokasi Waybalun $(45,49 \mathrm{Kg} / \mathrm{Ha})$ di Kab. Flores Timur dengan rata-rata sebesar $5.885,93 \mathrm{Kg} / \mathrm{Ha}$. Nilai Kelimpahan ikan karang tertinggi terdapat di lokasi Buffalo reef (66.236 Ind/Ha) di Kab. MBD dan yang terendah terdapat di Tanjung Soyang (186,67 Ind/Ha) di Kab. Alor dengan rata-rata sebsar 17.252,58 Ind/Ha (Tabel 2).Lokasi yang memiliki kelimpahan tinggi umumnya memiliki tutupan karang tinggi seperti lokasi buffalo reef yang memiliki tutupan karang $80,33 \%$ serta berkontur miring hingga terjal (drop off). Hal inilah yang menyulitkan perusak karang (bom) untuk beraktifitas, berbeda dengan lokasi yang landai seperti di Tanjung soyang, meski memiliki tutupan berkategori sedang (33,3\%) lokasinya banyak ditemukan kerusakan berupa patahan karang akibat pengeboman. Biomassa dan kelimpahan ikan karang di Kab. MBD sangat besar yang berpotensi menjadi pensuplai komoditas ikan karang dan sesuai dengan kebijakan pemerintah dimana Maluku dijadikan sebagai lumbung ikan nasional (Bawole dan Apitulay, 2011).

Tabel 3. Rata-rata Kelimpahan dan biomassa ikan karang di 3 kabupaten.

\begin{tabular}{clcc}
\hline Kabupaten & Lokasi & $\begin{array}{c}\text { Kelimpahan } \\
\text { (No.Ha-1) }\end{array}$ & $\begin{array}{c}\text { Biomassa } \\
\text { (Kg.ha-1) }\end{array}$ \\
\hline \multirow{2}{*}{ Alor } & Babylon & 52072 & 10751.69 \\
& Bangkalan/ & 26888 & 5575.86
\end{tabular}




\begin{tabular}{|c|c|c|c|}
\hline \multicolumn{4}{|c|}{ Desa Ombay } \\
\hline & Baulaung & 3532 & 1126.82 \\
\hline & Clownfish valley & 26788 & 1720.32 \\
\hline & Desa Aimole & 9584 & 2312.52 \\
\hline & Desa Pandai & 8472 & 1596.22 \\
\hline & Karang Le & 1093.33 & 493.17 \\
\hline & Kolana Utara & 1936 & 549.02 \\
\hline & Lemma & 3708 & 1083.96 \\
\hline & Mademang & 672 & 336.8 \\
\hline & Mahi & 666.67 & 210.46 \\
\hline & Marutaing 2 & 4008 & 1281.73 \\
\hline & Mausamang & 5208 & 896.35 \\
\hline & Pulau Batang & 11024 & 4033.18 \\
\hline & Pulau Kambing & 8664 & 2101.97 \\
\hline & Pulau Kangge & 1140 & 368.72 \\
\hline & Pulau Pura & 5256 & 889.66 \\
\hline & Pulau Rusa & 1436 & 632.3 \\
\hline & Pulau Ternate & 5688.89 & 733.63 \\
\hline & Sawarana & 2344 & 881.21 \\
\hline & Tanjung Ikara & 1112 & 542.41 \\
\hline & Tanjung Soyang & 186.67 & 489.8 \\
\hline & Taramana & 1784 & 1088.73 \\
\hline & The Boardroom & 41016 & 2207.7 \\
\hline \multirow{18}{*}{$\begin{array}{l}\text { Flores } \\
\text { Timur }\end{array}$} & Adonara & 1776 & 386.4 \\
\hline & Aran & 1844 & 326.55 \\
\hline & Batu Payung & 2480 & 2521.78 \\
\hline & Desa Balaweling & 832.5 & 267.6 \\
\hline & Hurung & 946.67 & 177.19 \\
\hline & Ile Padung & 4096 & 415.64 \\
\hline & Karang Sarbete & 15932 & 2029.62 \\
\hline & Kolidateng & 1092 & 193.48 \\
\hline & Koten & 1352 & 647.49 \\
\hline & Lamawalang & 1216 & 258.45 \\
\hline & Lato & 1924 & 386.84 \\
\hline & Lowoingu & 6528 & 1910.74 \\
\hline & Pulau Tiga & 4112 & 1272.5 \\
\hline & Pulo Mas & 2148 & 380.36 \\
\hline & Tanjung Naga & 944 & 150.3 \\
\hline & Watowati & 1980 & 376.68 \\
\hline & Watupeni & 38088 & 2204.77 \\
\hline & Waybalun & 644 & 45.5 \\
\hline
\end{tabular}




\begin{tabular}{clcc}
$\begin{array}{c}\text { Maluku } \\
\text { Barat Daya }\end{array}$ & Amortaun & 31824 & 7481.37 \\
& Babar Sea mount & 63776 & 42284.78 \\
& Buffalo reef & 66236 & 35751.42 \\
& Grouper fate & 18092 & 6672.47 \\
Jagotutun (Magic Corner) & 19196 & 20569.61 \\
North Moa & 25508 & 3512.48 \\
North Reong & 25668 & 2721.94 \\
North Romang & 23132 & 1705.9 \\
North West lakor & 28788 & 10892.55 \\
Pulau Kelapa & 33716 & 14274.99 \\
Pulau Laut & 21972 & 6109.59 \\
Pulau Nyata & 31592 & 9916.62 \\
South Reong & 34584 & 15517.07 \\
Tanjung Nunukae & 45705 & 24108.26 \\
Tanjung Ruswawan & 53948 & 16658.4 \\
Tanjung Wahar & 52640 & 24674.42 \\
Tanjung Yautu & 32304 & 20705.29 \\
To Dai For & 28036 & 11677.23 \\
West Moa & 50940 & 29262.02 \\
\hline
\end{tabular}

Pengelompokkan berdasarkan tipe pemakannya, rata-rata tipe pemakan yang dijumpai di tiga kabupaten tersebut untuk nilai biomassanya tertinggi berasal dari kelompok Planktivore (49\%) yang berasal dari famili Caesionidae (ekor kuning) dan Pomacentridae (damsel fish). Nilai biomasa terendah dari kelompok Coralivora $(0,39 \%)$ dari famili Chaetodontidae (Buterfly fish). Kecilnya kelimpahan ikan corallivore dimana ikan ini banyak dijadikan ikan indicator kesehatan terumbu karang (Crosby and Reese, 2005) memberikan sinyal negatif mengenai kesehatan karang. Pemilihan spesifik pucuk tip karang oleh coralivore dimana dalam kondisi ekosistem yang baik dapat tumbuh, namun sedikitnya ikan coralivore mengindikasikan pertumbuhan karang yang tidak sehat. Jika berdasarkan kelimpahannya nilai tertinggi berasal dari kelompok Planktivore (75\%) dan terendah dari kelompok Detritivora (1,29\%) (Gambar 4). Kelimpahan Planktivora selalu umum di area terumbu karang seperti penelitian yang dilakukan Pardede et al., (2015) di Taman Nasional Takabonerate; Tarigan et al., (2015) di Kabupaten Bima dan Dompu serta Setiawan et al., (2014) di Kep. Tanimbar.

Tingginya nilai biomassa dan kelimpahan ikan planktivore menunjukkan lokasi tersebut kaya akan plankton yang menjadi produsen dalam sistem rantai makanan. Wilayah ini berdasarkan Ilahude dan Gordon (1996) dilewati arus lintas Indonesia (ARLINDO) yang membawa massa air yang kaya akan plankton. Plankton sendiri dapat juga dimakan oleh hewan karang (Timotius, 2004) meski (75-99\%) makanan karang bersumber dari zooxanthellanya (Tackett and Tackett, 2002). 


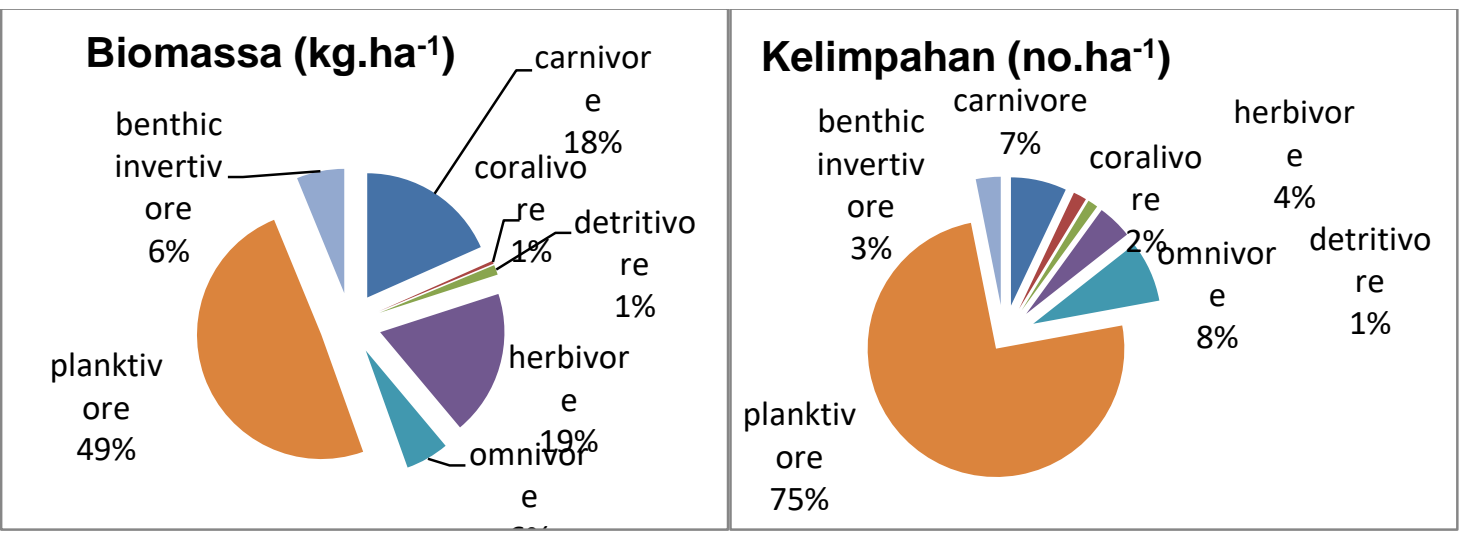

Gambar 4. Nilai biomassa dan kelimpahan ikan karang berdasarkan tipe pemakannya.

\section{Indeks Ekologi}

Nilai Indeks ekologi menggunakan Indeks keanekaragaman $\left(\mathrm{H}^{\prime}\right)$, keseragaman $(\mathrm{E})$ dan dominansi (C) spesies yang digunakan dalam menilai kesetabilan suatu komunitas (Odum, 1971). Hasil yang didapat selama penelitian menunjukkan indeks keanekaragaman berada pada kategori rendah hingga tinggi, berkisar antara $0,30-$ 3,34 dengan nilai rata-rata 2,91 (Tabel 5). Nilai keanekaragaman ini menunjukkan bahwa keseluruhan lokasi masuk kategori sedang. Menurut Odum (1971) bahwa semakin besar nilai keanekaragaman $\left(\mathrm{H}^{\prime}\right)$ menunjukkan komunitas semakin beragam dan indeks keanekaragaman tergantung dari variasi jumlah spesies yang terdapat dalam suatu habitat. Indeks keanekaragaman tertinggi terdapat di lokasi Pulau Laut di Kab. $\operatorname{MBD}(3,21)$ dan terendah di lokasi Pulau Pura di Kab. Alor $(0,30)$. Hal ini diduga terjadi tekanan terhadap komunitas baik dari lingkungan maupun aktifitas manusia. Nilai indeks keseragaman (E) menunjukkan kesetabilan sebuah komunitas. Nilai E dimana semakin mendekati 1 menunjukan komunitas semakin stabil dan jika semakin mendekati 0, maka komunitas semakin tertekan (Setyobudiandy et al. 2009 dalam Latuconsina et al. 2012). Menurut Odum (1971) indeks keseragaman (E) menggambarkan ukuran jumlah individu antar spesies dalam suatu komunitas ikan. Semakin merata sebaran individu antar spesies maka keseimbangan komunitas akan semakin baik. Indeks keseragaman tertinggi terdapat di lokasi Desa Balaweling di Kab. Flores Timur sebesar 0,82 dan terendah di Pulau Pura di Kab. Alor sebesar 0,06 dengan rata - rata 0,49 . Nilai tersebut masuk dalam kategori tertekan hingga stabil dengan rata -rata masuk kategori labil (Tabel 5).

Tabel 4. Kriteria struktur komunitas (Setyobudiany et al., 2009 dalam Latuconsina, 2012)

\begin{tabular}{cll}
\hline indeks & Kisaran & Kategori \\
\hline \multirow{3}{*}{ Keanekaragaman $\left(\mathrm{H}^{\prime}\right)$} & $\mathrm{H}^{\prime} \leq 2$ & rendah \\
& $2,0<\mathrm{H}^{\prime} \leq 3$ & Sedang \\
& $\mathrm{H}^{\prime} \geq 3,0$ & Tinggi \\
\hline \multirow{3}{*}{ Keseragaman $(\mathrm{E})$} & $0,00<\mathrm{H}^{\prime} \leq 0,50$ & Komunitas dalam kondisi tertekan \\
& $0,50<\mathrm{H}^{\prime} \leq 0,75$ & Komunitas dalam kondisi labil \\
& $0,75<\mathrm{H}^{\prime} \leq 1,00$ & Komunitas dalam kondisi stabil \\
\hline \multirow{2}{*}{ Dominansi $(\mathrm{C})$} & $0,00<\mathrm{H}^{\prime} \leq 0,50$ & rendah \\
& $0,50<\mathrm{H}^{\prime} \leq 0,75$ & Sedang \\
& $0,75<\mathrm{H}^{\prime} \leq 1,00$ & Tinggi \\
\hline
\end{tabular}

Nilai Dominansi $(C)$ berkisar antara 0 hingga 1 dimana apabila nilainya mendekati 1 menunjukkan terjadinya dominasi spesies, begitu juga jika nilainya mendekati 0 dimana tidak ada dominasi oleh salah satu spesies (Setyobudiandy et al., 2009 dalam 
Latuconsina et al.,, 2012). Nilai dominansi (C) tertinggi terdapat di lokasi Pulau Pura $(0,89)$ dan terendah di lokasi Pulau Laut $(0,05)$ dengan rata-rata 0,25 (Tabel 4). Hasil penelitian menunjukan semua lokasi masuk dalam kategori dominansi rendah hingga tinggi dengan rata-rata masuk kategori dominansi rendah. Odum (1971) menyatakan indeks keanekaragaman ( $\left.\mathrm{H}^{\prime}\right)$ dan keseragaman (E) bersifat terbalik dengan indeks dominansinya. Nilai $\mathrm{H}^{\prime}$ dan $\mathrm{E}$ yang tinggi menunjukkan tingkat dominansi yang rendah. Pulau Pura dimana indeks keanekaragamannya rendah dan dominansinya tinggi menunjukan kondisi ekosistem terumbu karangnya sedang mengalami tekanan, hal ini sangat wajar terjadi karena Pulau Pura merupakan lokasi pariwisata yang ditetapkan dalam KKPD Kab. Alor.

Tabel 5.Nilai Indeks Keanekaragaman (H'), keseragaman (e) dan dominansi (C) di 3 Kabupaten

\begin{tabular}{|c|c|c|c|c|}
\hline Region & Site Name & $\mathbf{H}^{\prime}$ & e & c \\
\hline \multirow{24}{*}{ Alor } & Babylon & 2.18 & 0.32 & 0.62 \\
\hline & Bangkalan/Desa Ombay B & 0.51 & 0.08 & 0.80 \\
\hline & Baulaung B & 2.65 & 0.75 & 0.08 \\
\hline & Clownfish valley & 2.40 & 0.42 & 0.15 \\
\hline & Desa Aimole B & 2.88 & 0.61 & 0.11 \\
\hline & Desa Pandai B & 0.90 & 0.16 & 0.72 \\
\hline & Karang Le B & 2.15 & 0.58 & 0.13 \\
\hline & Kolana Utara B & 1.88 & 0.39 & 0.26 \\
\hline & Lemma & 1.06 & 0.18 & 0.57 \\
\hline & Mademang B & 2.23 & 0.76 & 0.13 \\
\hline & Mahi B & 1.96 & 0.68 & 0.18 \\
\hline & Marutaing 2 & 2.34 & 0.63 & 0.13 \\
\hline & Mausamang B & 0.50 & 0.08 & 0.84 \\
\hline & Pulau Batang B & 2.73 & 0.70 & 0.08 \\
\hline & Pulau Kambing B & 1.79 & 0.56 & 0.20 \\
\hline & Pulau Kangge B & 2.31 & 0.60 & 0.12 \\
\hline & Pulau Pura B & 0.30 & 0.06 & 0.89 \\
\hline & Pulau Rusa B & 2.32 & 0.80 & 0.10 \\
\hline & Pulau Ternate B & 2.19 & 0.56 & 0.16 \\
\hline & Sawarana B & 0.94 & 0.20 & 0.57 \\
\hline & Tanjung Ikara B & 2.37 & 0.74 & 0.10 \\
\hline & Tanjung Soyang & 1.48 & 0.76 & 0.27 \\
\hline & Taramana B & 2.23 & 0.76 & 0.13 \\
\hline & The Boardroom & 2.21 & 0.35 & 0.21 \\
\hline \multirow{9}{*}{$\begin{array}{c}\text { Flores } \\
\text { timur }\end{array}$} & Adonara B & 2.61 & 0.73 & 0.09 \\
\hline & Aran B & 2.36 & 0.62 & 0.12 \\
\hline & Batu Payung B & 2.61 & 0.74 & 0.10 \\
\hline & Desa Balaweling B & 1.89 & 0.82 & 0.16 \\
\hline & Hurung B & 2.71 & 0.80 & 0.07 \\
\hline & Ile Padung B & 2.40 & 0.69 & 0.13 \\
\hline & Karang Sarbete & 2.53 & 0.45 & 0.14 \\
\hline & Kolidateng B & 2.01 & 0.67 & 0.18 \\
\hline & Koten B & 2.51 & 0.75 & 0.10 \\
\hline
\end{tabular}




\begin{tabular}{llll}
\hline & & & \\
Lamawalang B & 2.24 & 0.62 & 0.12 \\
Lato B & 2.48 & 0.75 & 0.10 \\
Lowoingu B & 2.42 & 0.61 & 0.15 \\
Pulau Tiga B & 1.87 & 0.43 & 0.27 \\
Pulo Mas B & 1.99 & 0.78 & 0.15 \\
Tanjung Naga B & 1.98 & 0.61 & 0.17 \\
Watowati B & 1.84 & 0.43 & 0.34 \\
Watupeni & 1.87 & 0.31 & 0.32 \\
\hline Amortaun & 2.44 & 0.39 & 0.16 \\
Babar Sea mount & 2.77 & 0.46 & 0.12 \\
Buffalo reef & 1.28 & 0.16 & 0.53 \\
Grouper fate & 2.72 & 0.48 & 0.15 \\
Jagotutun (Magic Corner) & 2.37 & 0.38 & 0.21 \\
Karang Barasadi & 2.93 & 0.47 & 0.08 \\
North Moa & 2.65 & 0.43 & 0.15 \\
North Reong & 2.65 & 0.46 & 0.12 \\
North Romang & 2.93 & 0.53 & 0.08 \\
North West lakor & 2.49 & 0.42 & 0.17 \\
Pulau Kelapa & 1.75 & 0.27 & 0.42 \\
Pulau Laut & 3.34 & 0.63 & 0.05 \\
Pulau Nusnitu & 2.55 & 0.45 & 0.16 \\
Pulau Nyata & 1.72 & 0.28 & 0.47 \\
South Reong & 1.82 & 0.31 & 0.44 \\
Tanjung Nunukae & 1.87 & 0.27 & 0.26 \\
Tanjung Ruswawan & 2.64 & 0.38 & 0.10 \\
Tanjung Siota & 1.94 & 0.28 & 0.30 \\
Tanjung Wahar & 0.85 & 0.11 & 0.61 \\
Tanjung Yautu & 2.11 & 0.35 & 0.28 \\
To Dai For & 2.08 & 0.33 & 0.31 \\
West Moa & 2.84 & 0.47 & 0.11 \\
\hline
\end{tabular}

\section{Kesamaan spesies ikan karang}

Hasil Cluster analysis pada taraf penskalaan dendogram $66,37 \%$ yang merupakan nilai rata-rata dari indeks similaritas Bray-Curtis antar stasiun diperoleh 5 pengelompokkan yaitu Adonara (merah), grup MBD (hijau), Grup Alor-Flotim (biru), Lowoingu (oranye) dan Tanjung Soyang (pink). Secara kasar terlihat perbedaan grup besar berdasarkan warna garisnya yaitu ikan karang di wilayah
Kabupaten Alor dan Flores Timur mengelompok dan Kabupaten Maluku Barat Daya di kolompok lainnya. Ini mengindikasikan ikan karang yang berada di Kab. Alor dan Flores timur memiliki kesamaan spesiesnya dan Kab. Maluku Barat Daya memisah mengelompok sendiri dan ini mencirikan Kab. MBD satu wilayah yang ikan karangnya banyak yang tidak sama dengan Kabupaten tetangganya. 


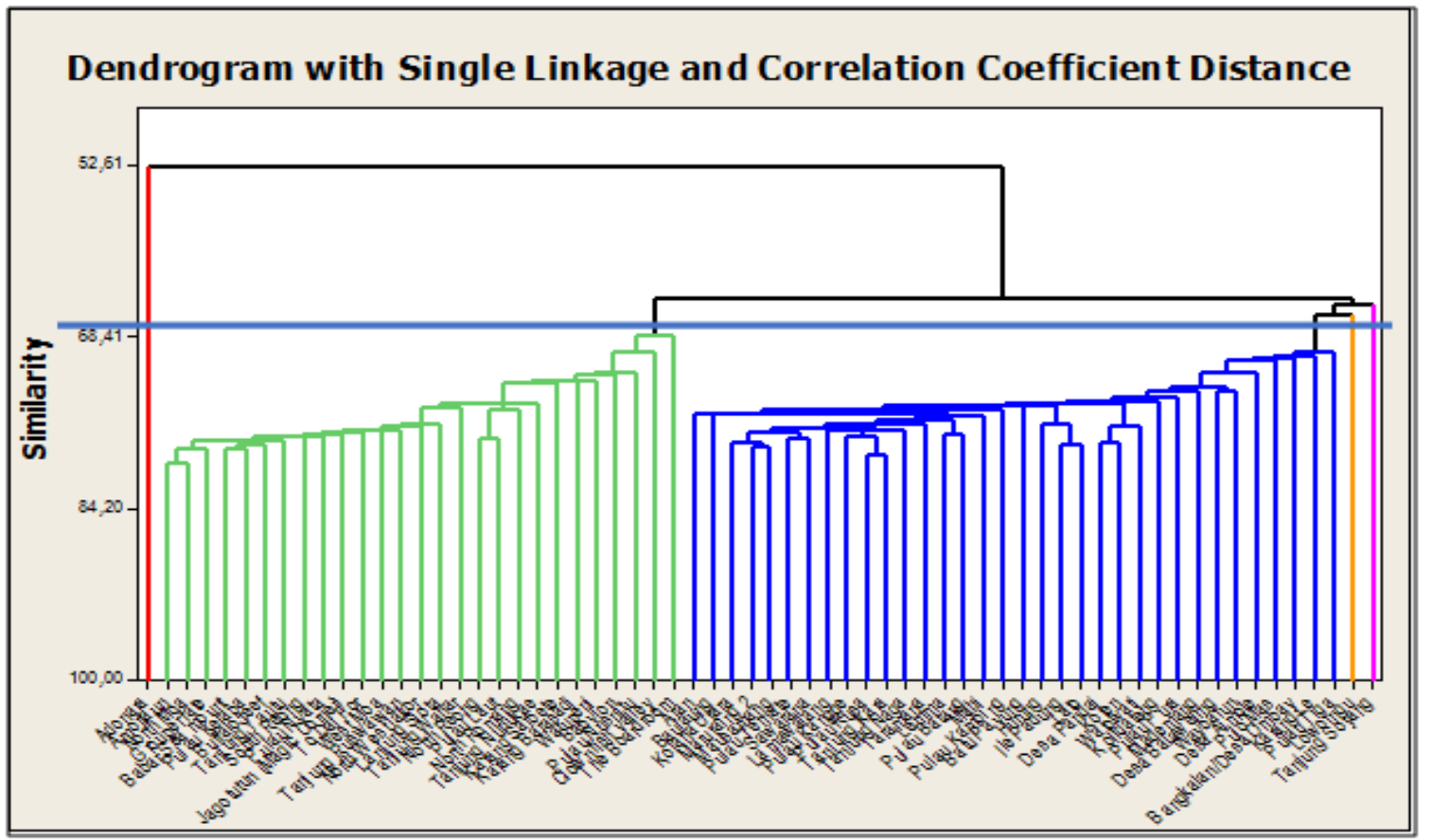

Gambar 6. Dendogram analsisis klaster pengelompokkan komunitas ikan karang di 62 lokasi penelitian di 3 kabupaten.

Hasil analisis ordinasi menggunakan MDS lebih terlihat lebih baik dalam pengelompokkannya dimana terdapat 2 pengelompokkan besar dimana lingkaran hitam yang kecil merupakan lokasi-lokasi di Kab. Maluku Barat Daya yang mengelompok berdasarkan kesamaan spesies ikan karang dan lingkaran besar biru merupakan lokasilokasi di Kabupaten Alor dan Flores Timur. Lokasi Adonara terpisah dari kelompok manapun hal ini dikarenakan lokasi ini terdapat ikan karang baik dari kelompok Alor-
Flotim maupun dari Maluku Barat Daya. Hal inilah yang menyebabkan Lokasi Adonara tidak masuk kedalam kelompok manapun dalam ordinasinya. Hasil dari analisis klatser dan MDS memperlihatkan Kab. Alor dan Flores timur di Provinsi NTT yang masuk wilayah geografis Lesser Sunda memiliki perbedaan ikan karang dengan Kab. Maluku Barat Daya di Provinsi Maluku yang secara geografis masuk area Sunda Banda seascapes. 


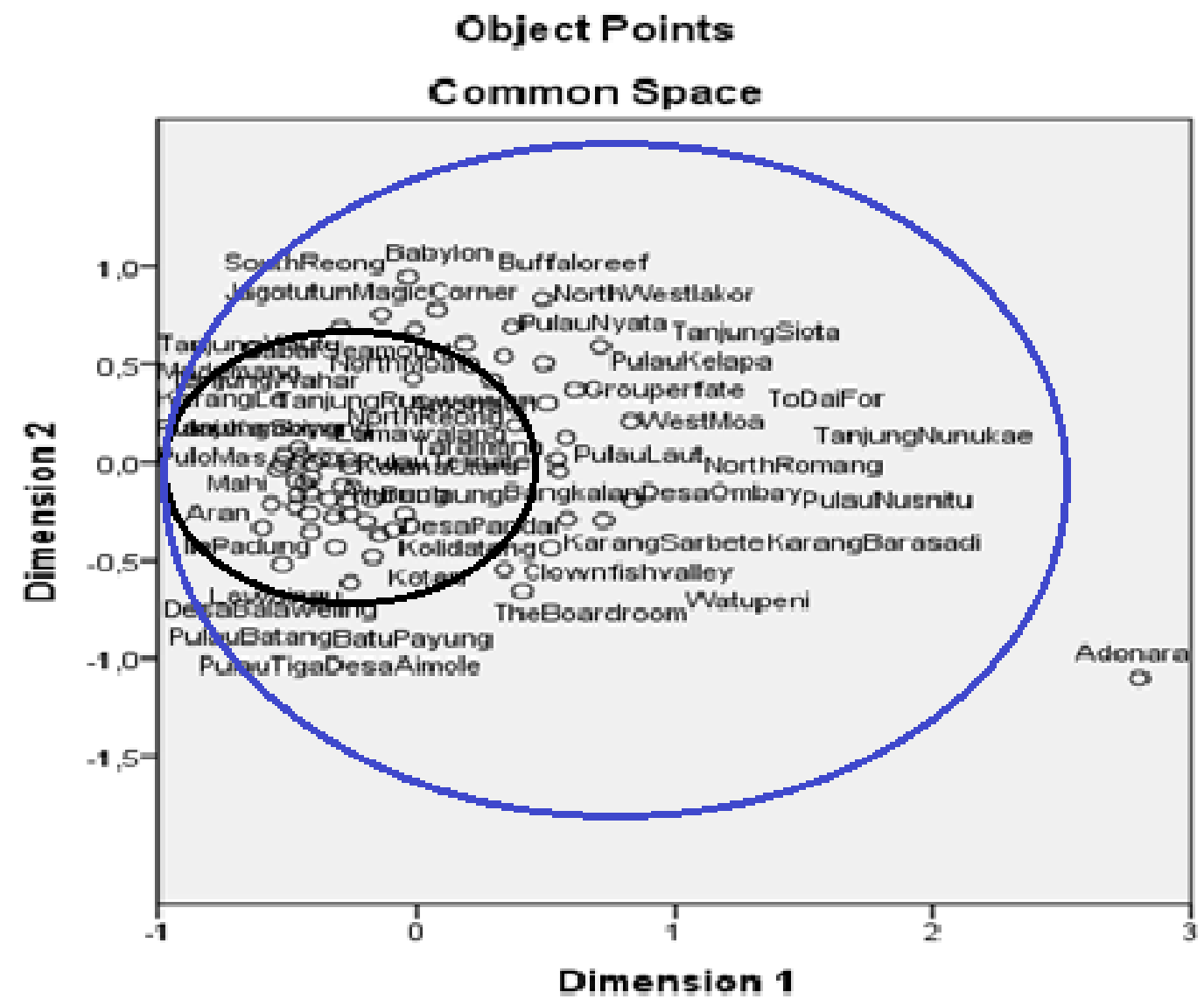

Gambar 6. Hasil pengelompokkan menggunakan MDS berdasarkan indeks Bray-Curtis di 62 lokasi penelitian di 3 kabupaten.

\section{KESIMPULAN}

Hasil yang dapat disimpulkan dari penelitian ini yaitu:

1. Ikan karang yang ditemukan dalam survei terdiri dari 468 Spesies dalam 47 Famili ikan karang.Nilai Kelimpahan ikan karang tertinggi terdapat di Kab. MBD (rata-rata 13.308 ind.ha $^{-1}$ ) dan yang terendah terdapat di Kab. Flores Timur (ratarata 1.502 .23 ind.ha $^{-1}$ ).

2. Biomassa ikan karang tertinggi terdapat Kab. MBD (Rata-rata 12.476,32 kg.ha-1) sedangkan yang terendah terdapat di Kab. Flores Timur (rata-rata 652,83 kg.ha-1 ${ }^{-1}$.

3. Nilai ekologi berdasarkan struktur komunitas ikan karang mengkategorikan nilai indeks shanon-weinner berada kategori rendah hingga tinggi, berkisar antara $0,30-3,34$ dengan nilai rata-rata
2,91 ini menunjukkan bahwa keseluruhan lokasi masuk kategori sedang. Nilai indeks keseragaman (E) menunjukkan rata - rata 0,49 masuk kategori labil. Nilai Dominansi (C) dengan rata-rata 0,25 dan masuk dominansi rendah.

4. Kesamaan spesies ikan karang mengelompokkan hasil analisis kluster pada taraf penskalaan dendogram 66,37\% memperlihatkan perbedaan ikan karang di wilayah Kabupaten Alor dan Flores Timur mengelompok dan Kabupaten Maluku Barat Daya di kolompok lainnya. Ini mengindikasikan ikan karang yang berada di Kab. Alor dan Flores timur memiliki kesamaan spesiesnya dan berbeda dengan Kab. Maluku Barat Daya yang memisah mengelompok. Hasil analisis ordinasi menggunakan MDS lebih terlihat lebih baik dalam pengelompokkannya dimana 
terdapat 2 pengelompokkan besar dimana lokasi di Kab. MBD berbeda kelompok dengan Kab. Alor dan Flores Timur.

\section{UCAPAN TERIMAKASIH}

Peneliti juga mengucapkan terimakasih yang setinggi-tingginya untuk WWF-Indonesia, karena berkat dukungan penuhnya maka penelitian ini dapat terselenggara. Penulis mengucapkan terimakasih yang sebesarbesarnya kepada kru kapal Menami atas kerjasamanya dalam melakukan ekspedisi serta semua pihak atas partisipasi aktifnya hingga penulisan ini dapat selesai sebagaimana mestinya.

\section{DAFTAR PUSTAKA}

Adrim, M., Hutomo, M., \& Suharti, S. R. (1991). Chaetodontid fish community structureand its relation to reef degradation at the Seribu Island reefs, Indonesia. In: Alcala, A. C. (ed): Proocedings of the regional symposium on living resources in coastal areas. Manila, Philippines: 163-174.

Adrim, M. (2007). Komunitas Ikan Karang di Perairan Pulau Enggano, Provinsi Bengkulu. Jurnal Oseanologi dan Limnologi Di Indonesia, 33, 139-158.

Adrim, M., Harahap, S. A., \& Wibowo, K. (2012). Struktur Komunitas Ikan Karang di Perairan Kendari. Jurnal IImu Kelautan, 17(3), 154-163.

Adriman, Purbayanto, A., Budiharsono, S., \& Damar, A. (2012). Kondisi Ekosistem Terumbu Karang di Kawasan Konservasi Laut Bintan Timur Kepulauan Riau. Jurnal Berkala Perikanan Terubuk, 40(1), 22-35.

Afandy, Z., \& Supeni, E. A. (2014). Kondisi Terumbu Karang di Pesisir Barat Pulau Kei Kecil, Kabupaten Maluku Tenggara. Neritik, 5(1), 8-14.

Ardiwijaya, L. R., Kartawijaya, T., Herdiana, Y., \& Setiawan, F. (2007). Technical Report-TheCoral Reefs of Northern Sumatra: An Ecological Survey of Weh and Aceh Islands, April 2006. WCS. Marine Program Indonesia. Bogor, Indonesia. 24pp.

Arifin, T., \& Kepel, T. L. (2013). Status Keberlanjutan Pengelolaan Terumbu Karang Di Pulau-Pulau Kecil Kota Makassar (Studi Kasus Di Pulau Barrang Lompo Dan Pulau Barrang Caddi). Jurnal Segara, 9(1), 1-12.
Bawole, D., \& Apituley, Y. M. T. N. (2011). Prosiding Seminar Nasional: Pengembangan Pulau-Pulau Kecil 2011.

http://ejournal.unpatti.ac.id/ppr_iteminfo Ink.php?id=281.( diakses 29 Maret 2016).

Burke, L., Reytar, K., Spalding, M., \$Perry, A. (2011). Reefs at Risk (Revisited). World Resources Institute. Washington DC 200002. USA. 114pp.

Campbell, S \& Crueck, N. (2014). Exploring Indonesia's last of the Wild-the Forgotten Islands. (http://voices.nationalgeographic.com/2 014/12/14/exploring-indonesias-last-ofthe-wild-the-forgotten-islands/) diakses 3/11/2016.

COREMAP, (2014). Kondisi terumbu karang di Indonesia.

(http://www.coremap.or.id/Kondisi-TK/) diakses 14/11/2016.

Crosby, M. P., \& Reese, E. S. (2005). Relationship of habitat stability and intraspecific population dynamics of an obligate corallivore butterflyfish. Aquatic Conservation: Marine and Freshwater Ecosystems, 15, S15-S25.

Dartnall, H. J., \& Jones, M. (1986). A manual of survey methods of living resources in coastal areas. Aseanautralia cooperative programme marine science handbook. Townsville: Australian institute of marine science. 167p.

Effendie, M. I. (1979). Metode Biologi Perikanan. Yayasan Dewi Sri. Bogor. $112 p$.

English, S., Wilkinson, C., \& Baker, V. (1997). Survei Manual for Tropical Marine Resources (2nd Edition). Australian Institute of Marine Science. Australia. $x$ $+390 \mathrm{~h}$.

Froese. R., \& Pauly, D. (2010). Editors. FishBase. World Wide Web electronic publication. www.fishbase.org, version (11/2010). [10 November 2014].

Gordon, A., \& Fine, R. A. (1996). Pathways of water between the Pacific and Indian Oceans in the Indonesian seas. Nature Journal, 379, 146 - 149.

Hallacher, L. E. (2003). The Ecology of Coral Reef Fishes. http: // www.kmec.uhh.hawaii.edu / QUESTInfo/Coral\%20Reef\%20Fishes\% 20-\%20May\%202003.pdf. Di akses 6 Februari 2015. 
Hasanuddin, M. (1998). Arus Lintas Indonesia (ARLINDO). Oseana, XXIII(2), 1-9.

Hill, J., \& Wilkinson, C. (2004). Methods for Ecological Monitoring of Coral Reefs: A Resource for Managers. Australian Institute of Marine Science and Reef Check, Australia.

Hieske, E., \& Myers, R. (2001). Reef Fishes of the World. Harper Collins Publishers. 400p.

Huffard, C. L., Erdmann, M. V., \& Gunawan, T. (Eds) (2012). Prioritas Geografi Keanekaragaman Hayati Laut untuk Pengembangan Kawasan Konservasi Perairan di Indonesia. Kementerian Kelautan dan Perikanan dan Marine Protected Areas Governance. JakartaIndonesia. $105 \mathrm{pp}$.

Hutomo, M. (1986). Komunitas Ikan Karang dan Metode Sensus Visual. LON LIPI. Jakarta.

Hutomo, M. (1995). Pengantar Ekologi Komunitas Ikan Karang dan Metode Pengkajiannya. P2O-LIPI. Jakarta.

llahude, A. G., \& Gordon, A. (1996). Thermocline Stratification within the Indonesian Seas. Journal of Geophysic Research, 101(C5), 12401-12409.

Kepmen Lingkungan Hidup No. 4. (2001). Kriteria Baku Kerusakan Terumbu Karang. Jakarta. Indonesia. 11 p.

Krebs, C. J. (1989). Ecological Methodology. Univ. of British Columbia. Harper Collins Publisher.645

Kuiter, R. H. (2001). Labroid Fishes Part 1. A Comprehensive Guide to Selected Labridae Groups. Zoonetics, Seaford, Australia. 105p.

Kuiter, R. H. (2010). Labridae Fishes: Wrasses: Aqiatic Photographics, Seaford, Australia. 393p.

Kuiter, R. H., \& Tonozuka, T. (2001a). Pictorial Guide to: Indonesia Reef Fishes. Zoonetics. Seaford Vic 3198. Australia. Volume 1. 302p.

Kuiter, R. H., \& Tonozuka, T. (2001b). Pictorial Guide to: Indonesia Reef Fishes. Zoonetics. Seaford Vic 3198. Australia. Volume 2. 622p.

Kuiter, R. H., \& Tonozuka, T. (2001c). Pictorial Guide to: Indonesia Reef Fishes. Zoonetics. Seaford Vic 3198. Australia. Volume 3. 865p.

Kulbicki, M., Guillemot, N., \& Amand, M. (2005). A General Aproach to LengthWeight Relationships for New
Caledonian Lagoon Fishes. Journal Cybium, 235-252p.

Latuconsina, H., Nessa, M. N., \& Rappe, R. A. (2012). Komposisi Spesies Dan Struktur Komunitas Ikan Padang lamun Di Perairan Tanjung Tiram-Teluk Ambon Dalam. Jurnal IImu dan Teknologi Kelautan Tropis, 4(1), 35-46.

Ludwig, J. A., \& Reynolds, J. F. (1988). Statistical Ecology: A Primer on Methods and Computing. John Wiley \& Sons, New York: xviii + $337 \mathrm{hlm}$.

Manuputty, A. E. W. (1990). Senyawa Terpen Dalam Karang Lunak (Octocorallia: Alcyonacea). Oseana, XV(2), 77-84.

Manuputty, A. E. W. (1996). Pengenalan Beberapa Karang Lunak (Octocorallia, Alcyonacea) di Lapangan. Oseana, $X X I(4), 1-11$.

Manuputty, A. E. W., \& Djuwariah. (2009). Panduan Metode Point Intercept Transect (PIT) untuk Masyarakat. COREMAP II - LIPI. 73pp.

Marnane et al. (2003). Laporan Teknis Survei 2003-2004 Di Kepulauan Karimunjawa, Jawa tengah. WCS.75p.

McKenna, S. A., Allen, G.R., \& Suryadi, R. (eds). (2002). A Marine Rapid Assessment of the Raja Ampat Islands, Papua Province, Indonesia. RAP Bulletin of Biolgical Assessment 22. Conservation International, Washington, DC. 191 pp.

Monk, K. A., Fretes, Y., \& Reksodiharjo-Lilley, G. (1997). The Ecology of Nusa Tenggara and Maluku. Hong Kong: Periplus Editions Ltd. p. 966.

Odum, E. P. (1971). Fundamental of ecology. W.B. Saunders co., Philadelphia: 574 pp.

Pardede, S., Muttaqien, E., Tarigan, S. A. R., \& Sadewa, S. (2014). Status Ekosistem Terumbu Karang Di Pulau Lombok, 2013. Wildlife Conservation Society. Bogor. Indonesia.73 hal.

Pardede, S., Tarigan, S. A. R. \& Setiawan, F., Muzrini, A., \& Muttaqien, E. (2015). Status Ekosistem Terumbu Karang Taman Nasional Takabonerate, 2015. Wildlife Conservation Society. Bogor. Indonesia.86 hal.

Richmond, R. H. (1997). Reproduction and recruitment in corals: critical links in the persistence of coral reefs. In C. Birkeland (ed.) Life and Death of Coral Reefs. Chapman and Hall, New York: 175-197. 
Salim, D. (2012). Pengelolaan ekosistem terumbu karang akibat pemutihan (Bleaching) dan rusak. Jurnal kelautan, $5(2)$.

Setiawan, F., Tarigan, S., Pardede, S., Muhidin, \& Mutaqin, A. (2015). Status Ekosistem Terumbu Karang di Perairan Tanimbar Kab. Maluku Tenggara Barat, 2014. Wildlife Conservation Society. Bogor. Indonesia. 47 hal.

Siringoringo, R. M., \& Hadi, T. A. (2013). Kondisi dan Distribusi Karang Batu (Scleractinia corals) Di Perairan Bangka. Jurnal IImu dan Teknologi Kelautan Tropis, 5(2), 273-285.

Tackett, D. N., \& Tackett, L. (2002). Reef Life: Natural History and Behaviors of Marine Fishes and Invertebrates. T.F.H. Publications, Inc., New Jersey: $224 \mathrm{hlm}$.

Tarigan, S. A., Setiawan, F., Pardede, S., Muhidin, \& Muzrin, A. (2015). Status Ekosistem Terumbu Karang Kabupaten Bima dan Dompu, 2015. Wildlife Conservation Society Indonesia Program. Bogor. Indonesia.

Tomascik, T., Mah, A. J., Nontji, A., \& Moosa, M. K. (1997). The ecology of Indonesian seas. Part I, Periplus Editions Ltd., Singapore.

Timotius, S. (2003). Makalah training course: Karakteristik Bilogi Karang. Yayasan terumbu Karang Indonesia (Terangi). p14.

Yulianto, I., Prasetia, R., Muttaqin, E., Kartawijaya, T., Paredede, S. T., Herdiana, Y., Setiawan, F., Ardiwijaya, R. L., \& Syahrir, M. (2012). Panduan Teknis Pemantauan Ekosistem Terumbu Karang, Padang Lamun dan Mangrove. Wildlife Conservation Society. Bogor. Indonesia. 143 hal.

Zamani, N. P., \& Madduppa, H. (2011). A Standard Criteria for Assesing the Health of Coral reefs: Implication for Management and Conservation. Journal of Indonesia Coral Reefs, 1(2), 137-146. 